\title{
A Microbiology Laboratory Workflow in the COVID-19 Pandemic: Trakya University Medical Faculty
}

\author{
COVID-19 Pandemisinde Bir Mikrobiyoloji Laboratuvarı Iş Akışı: Trakya Üniversitesi Tıp \\ Fakültesi Deneyimi
}

\author{
(D) İsmail DAVARCI, (D) Şaban GÜRCAN, (D) Berrak KAPLAN \\ Trakya University Faculty of Medicine, Department of Medical Microbiology, Edirne, Turkey
}

\begin{abstract}
Aim: The Coronavirus disease-2019 (COVID-19) epidemic first started in China and spread all over the world. In our country, pandemic management is carried out under the coordination of the Ministry of Health. With the change in the case increase rate in our province within months, the needs of our hospital were fully answered as the medical microbiology laboratory. In this study, it is aimed to convey our experiences and to make a retrospective analysis of the samples that came to the coronavirus laboratory in the first seven months of the pandemic.

Materials and Methods: In order to create a safe working environment and organize the workflow during the pandemic process, some changes were made in the laboratory and it was made a guide. In addition, Severe acute respiratory syndrome coronavirus-2 (SARS-CoV-2) polymerase chain reaction (PCR) and anti-SARS-CoV-2 antibody tests that came to the coronavirus laboratory between 21.03.2020 and 21.10.2020 were screened retrospectively.

Results: A total of 73,773 SARS-CoV-2 PCR tests and 1,170 anti-SARS-CoV-2 antibody tests were run in our laboratory. It was determined that total PCR positivity was $2.7 \%$ and antibody positivity was $1.9 \%$.

Conclusion: When the PCR positivity rates were examined, a dramatic decrease was observed after the first month with the measures taken and this decrease continued until the fifth month. It is seen that PCR positivity increased again in the sixth and seventh months with the relaxation of the measures. It is thought that our experiences in the first months of the pandemic can provide valuable information for other laboratories.
\end{abstract}

Keywords: COVID-19, pandemic, microbiology, laboratory

ÖZ

Amaç: Koronavirüs hastalığı-2019 (COVID-19) salgını ilk olarak Çin'de başlamış olup tüm dünyaya yayılmıştır. Ülkemizde salgın yönetimi Sağlık Bakanlığı koordinesinde yapılmaktadır. İlimizdeki olgu artış hızının aylar içinde değişmesiyle birlikte hastanemizde oluşan ihtiyaçlara tıbbi mikrobiyoloji laboratuvarı olarak eksiksiz cevap verilmiştir. Bu çalışmada bu deneyimlerimizi aktarmak ve pandeminin ilk yedi ayında koronavirüs laboratuvarına gelen örneklerin retrospektif analizini yapmak amaçlanmıştır.

Gereç ve Yöntem: Pandemi sürecinde güvenli bir çalışma ortamı oluşturmak ve iş akışını organize etmek için laboratuvar içinde birtakım değişiklikler yapılıp rehber haline getirilmiştir. Ayrıca 21.03.2020-21.10.2020 tarihleri arasında koronavirüs laboratuvarına gelen Şiddetli akut solunum sendromu koronavirüs-2 (SARS-CoV-2) polimeraz zincir reaksiyonu (PZR) ve anti-SARS-CoV-2 antikor testleri retrospektif olarak taranmıştır.

Bulgular: Laboratuvarımızda toplam 73.773 SARS-CoV-2 PZR testi, 1.170 anti SARS-CoV-2 antikor testi çalışılmıştır. Toplam PZR pozitifliğinin \%2,7, antikor pozitifliğinin ise \%1,9 olduğu tespit edilmiştir.

Sonuç: PZR pozitiflik oranları incelendiğinde alınan önlemler ile ilk aydan sonra dramatik bir düşük gözlenmekte ve bu düşüş beşinci aya kadar devam etmektedir. Önlemlerin gevşetilmesi ile altıncı ve yedinci aylarda PZR pozitifliğinin tekrar yükseldiği görülmektedir. Pandeminin ilk aylarında elde ettiğimiz deneyimlerimizin diğer laboratuvarlar için değerli bilgiler sağlayabileceği düşünülmektedir.

Anahtar Kelimeler: COVID-19, pandemi, mikrobiyoloji, laboratuvar

Address for Correspondence: İsmail DAVARCI MD, Trakya University Faculty of Medicine, Department of Medical Microbiology, Edirne, Turkey Phone: +90 5065361977 E-mail: ismaildavarci@trakya.edu.tr ORCID ID: orcid.org/0000-0002-5835-4237

Received: 14.06.2021 Accepted: 09.09.2021

๑Copyright 2021 by the Tekirdağ Namık Kemal University Faculty of Medicine / Namık Kemal Medical Journal published by Galenos Publishing House. 


\section{INTRODUCTION}

In December 2019, a number of cases consistent with viral pneumonia were reported from Wuhan, China'. As a result of the sequence analysis of these cases, it was revealed that this disease was caused by the new Coronavirus and it was named "2019-nCoV"1. This name was changed as "Severe acute respiratory syndrome coronavirus-2 (SARS-CoV-2)" on February 11, 2020 by the "International Virus Taxonomy Committee Coronavirus Working Group" and accepted worldwide ${ }^{2}$. On the same day, the World Health Organization (WHO) declared the name of this disease as "Coronavirus disease-2019 (COVID-19)"3. On March 11, 2020, WHO defined this outbreak as a pandemic ${ }^{3}$.

After the declaration of the pandemic, scientific committees were established in many countries. In our country, the "Coronavirus Scientific Committee" affiliated to the Ministry of Health was established on January 10, 2020. This committee consists of scientists from different branches such as Medical Microbiology, Infectious Diseases and Clinical Microbiology, Virology, Internal Medicine and Chest Diseases".

SARS-CoV-2 is the seventh Coronavirus (HCoV) known to infect humans. Among these viruses, HCoV-229E, HCoV-NL63, $\mathrm{HCoV}-\mathrm{HKU} 1$ and $\mathrm{HCoV}-\mathrm{OC} 43$ are endemic. These four viruses are seasonal and tend to cause mild respiratory illness. The other two viruses are the more virulent zoonotic Middle east respiratory syndrome coronavirus and SARS-CoV type 1 (SARSCoV-1). SARS-CoV-2 is most genetically similar to SARS-CoV-1, and both of these viruses belong to the Sarbecovirus subgenus within the Betacoronavirus genus 5 . The clinical manifestation of SARS-CoV-2 infection can range from asymptomatic infection to severe disease. Mortality rates vary by country ${ }^{6}$. Early laboratory diagnosis of SARS-CoV-2 infection can help clinical management and pandemic control. The definitive diagnosis of the disease is established by genetic tests such as polymerase chain reaction (PCR) or gene sequencing?.

\section{Timeline}

January 10, 2020: The Coronavirus Scientific Committee was established under the coordination of the Ministry of Health ${ }^{8}$.

January 24, 2020: With the recommendation of the Scientific Committee, flights to Wuhan were stopped, and measures such as scanning with thermal cameras for those coming from China to our country were determined. It was decided to quarantine people showing symptoms of COVID-199.

February 04, 2020: Scanning with thermal cameras at entry points for passengers arriving from countries where the disease was reported was begun ${ }^{8}$.

March 5, 2020: It was underlined that everyone entering our country from other countries should pay attention to the "14 days" rule. According to this rule, it was stated that people coming from abroad should isolate themselves as much as possible for 14 days, and that they should not contact with people over the age of 65 years who were in the risk group and who had chronic diseases ${ }^{10}$.

March 11, 2020: The first case of COVID-19 was detected in Turkey.

March 12, 2020: Education was suspended in primary and secondary schools and universities ${ }^{8}$.

March 12, 2020: Public officers were prohibited from going abroad except in compulsory and urgent situations ${ }^{11}$.

March 13, 2020: Collective events in public areas were restricted ${ }^{8}$.

March 13, 2020: Bulgaria closed its borders to passenger entries and exits, except for trucks carrying loads, within the scope of COVID-19 measures. Although Turkey stopped the quarantine on June 11, the Bulgarian government continued the application until September 1 on the grounds that the COVID-19 epidemic continued ${ }^{12}$.

March 16, 2020: Congregational prayers in mosques were suspended ${ }^{8}$.

March 20, 2020: All kinds of artistic, cultural and scientific activities were postponed. On the same date, all hospitals with a tertiary adult intensive care unit with at least two specialist physicians in the branches of chest diseases, infectious diseases, clinical microbiology and internal medicine were declared as pandemic hospitals by the Ministry of Health ${ }^{13}$.

March 21, 2020: The number of test centers detecting COVID-19 was increased to 73 , and on this date, a lockdown was imposed for those over the age of 65 years and with chronic diseases. Hairdressers and beauty centers were temporarily closed. Restaurants were only allowed to provide take-out services ${ }^{8}$.

March 22, 2020: Working hours were re-organized for public sector employees ${ }^{8}$.

April 04, 2020: A lockdown was also imposed for those younger than 20 years old ${ }^{8}$.

April 14, 2020: Turkish Airlines announced that it suspended international flights until May 20, 2020 ${ }^{14}$.

May 04, 2020: As part of normalization, travel restrictions were stopped for seven provinces, and it was announced that hairdressers and shopping centers would reopen on May $11^{8}$.

May 29, 2020: Within the scope of normalization in public institutions and organizations, international travel ban and flexible working of public officers were discontinued ${ }^{15}$.

August 26, 2020: It was decided that flexible working could be applied again at the initiative of the managers in public institutions ${ }^{16}$. 
September 7, 2020: It was made obligatory to wear masks in all areas (except residences) in 81 provinces $^{17}$.

October 2, 2020: All events organized by non-governmental organizations, public institutions, cooperatives and unions were postponed until December $1^{18}$.

In the COVID-19 pandemic, there have been significant changes in working life with the decisions taken both in the country and in our university. In this process, different arrangements were made in the services of the medical microbiology laboratory and the distribution of personnel, and the needs related to the COVID-19 pandemic were tried to be met. In this study, it was aimed to convey the experiences of the medical microbiology laboratory during the pandemic process and to investigate the SARS-CoV-2 PCR and anti-SARS-CoV-2 antibody positivity rates in the first seven months.

\section{MATERIALS AND METHODS}

Permission was obtained from the Ministry of Health to conduct the study. In addition, the study was approved by the Scientific Research Ethics Committee of Trakya University (TUTF-BAEK 2021/70, date: 21.12.2020). Descriptive statistics for categorical variables were presented as numbers and percentages, and SPSS (ver: 21) statistical program was used for all statistical analyses.

\section{a. Preanalytical Process}

There is a molecular diagnosis laboratory in our medical microbiology laboratory. However, it was not possible to study SARS-CoV-2 PCR tests in this laboratory due to both biosafety and physical inadequacy. Instead, the tuberculosis laboratory with Biosafety level-2 (BSL-2) was modified and used. On March 21, 2020, "Trakya University Medical Faculty
Coronavirus Laboratory" started to work with five technicians, three medical microbiology assistants and three academic members.

Tuberculosis tests were directed to Edirne Public Health Laboratory to be studied in this process. In addition, molecular tests, immunofluorescent antibody tests, parasitology tests and bacteriology tests were temporarily closed on April 9, 2020, as the technicians working here were working in the coronavirus laboratory (Table 1).

The coronavirus laboratory consists of three rooms. In the first room, there is a computer where the results are entered and documents. The second room is the room where the PCR device is located and the staff change their clothes. In the innermost room, the samples are opened and processed in the BGD-2 biosafety cabinet. From the date of its opening, the laboratory served 24 hours a day, 7 days a week, until October 1, 2020, with two technicians and a medical microbiology assistant. Due to the increased workload with this situation, technicians with experience of PCR in medical biology, medical genetics and Trakya University Technology Research and Development Application and Research Center PCR were requested to be assigned to our laboratory. In April, the coronavirus laboratory continued to serve with five additional personnel assigned in addition to the existing personnel and two medical microbiology assistants on standby. In June, three personnel assigned from other departments left the laboratory due to the expiry of their assignment period, and two technicians working in the medical microbiology laboratory started to work in the coronavirus laboratory. In addition, a medical microbiology assistant started to work in this process and was assigned to the coronavirus laboratory. Moreover, by talking to the head physician, it was ensured that the new technicians in our hospital were also started to work in the medical microbiology

\section{Table 1. Change of open-closed status of laboratories according to months}

\begin{tabular}{|c|c|c|c|c|c|c|c|c|}
\hline Months & Labor force & Bacteriology & Tuberculosis & Parasitology & IFA & Molecular & Mycology & Serology \\
\hline March & 5 technicians +3 assistants & Open & Open & Open & Open & Closed & Open & Open \\
\hline April & $\begin{array}{l}5 \text { technicians }+5 \text { assistants }+5 \\
\text { assignments }\end{array}$ & Closed & Closed & Closed & Closed & Closed & Open & Open \\
\hline May & $\begin{array}{l}5 \text { technicians }+5 \text { assistants }+5 \\
\text { assignments }\end{array}$ & Open & Open & Closed & Closed & Closed & Open & Open \\
\hline June & $\begin{array}{l}7 \text { technicians }+6 \text { assistants }+2 \\
\text { assignments }\end{array}$ & Open & Open & Open & Closed & Closed & Open & Open \\
\hline July & $\begin{array}{l}7 \text { technicians }+6 \text { assistants }+2 \\
\text { assignments }\end{array}$ & Open & Open & Open & Closed & Closed & Open & Open \\
\hline August & $\begin{array}{l}8 \text { technicians }+6 \text { assistants }+2 \\
\text { assignments }\end{array}$ & Open & Open & Open & Closed & Open & Open & Open \\
\hline September & $\begin{array}{l}7 \text { technicians }+6 \text { assistants }+2 \\
\text { assignments }\end{array}$ & Open & Open & Open & Open & Open & Open & Open \\
\hline
\end{tabular}


laboratory. A total of six technicians, one in August and five in October, started to work in our laboratory, five of them were assigned to the coronavirus laboratory. On October 1 , due to the decrease in the samples, two people continued the shifts. As of October 2020, the coronavirus laboratory provided uninterrupted service with 14 technicians and six medical microbiology assistants.

The COVID-19 guideline prepared by the Ministry of Health was updated five times in the first seven months of the pandemic. Except for the guideline published on April 13, 2020, the possible case definition changed in each update. The variation of the probable case definition is shown in Table 2.

Individuals suitable for the possible case definition were registered in the "Hospital Information Management System (HIMS)" and reported to e-nabız. SARS-CoV-2 PCR request was made for the diagnosis of COVID-19 via HIMS. The appropriately taken sample was delivered to the laboratory under appropriate conditions.

\section{Collecting and Delivering Samples}

Respiratory tract samples from probable or definite cases of COVID-19 were taken by healthcare personnel. The most common types of specimens taken for testing were combined swab specimens from the nasopharynx and oropharynx, which were taken together and sent in the same tube. Lower respiratory tract secretions, such as sputum and brochoalveolar lavage fluid, were also tested in patients with pneumonia.

Taking oropharyngeal swab: The inside of the mouth is illuminated so that it can be seen clearly. The tongue is pressed down with the tongue depressor and a sample is taken from the tonsils with a sterile ecuvion. During this process, strict attention is paid not to let the swab touch other points in the mouth ${ }^{19}$.

\section{Table 2. Change of probable case definition in COVID-19 guidelines in the first 7 months}

\begin{tabular}{|c|c|c|}
\hline \multirow{3}{*}{ 유 } & \multirow{3}{*}{1} & Those having *SARI that cannot be explained with another etiology and having one of the followings: \\
\hline & & a. Having a history of travel to China 14 days before the onset of symptoms \\
\hline & & b. Working in the unit where COVID-19 patients are treated \\
\hline \multirow{4}{*}{ 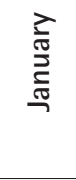 } & \multirow{4}{*}{2} & Those having respiratory disease and any of the followings: \\
\hline & & a. Close contact with a confirmed COVID-19 patient \\
\hline & & b. Being in a healthcare facility in a country where hospital-associated COVID-19 has been reported \\
\hline & & c. Having been in China \\
\hline \multirow{5}{*}{ 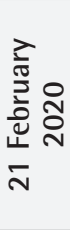 } & & Those having respiratory disease or SARI and having any of the followings in the past 14 days \\
\hline & & a. Close contact with a confirmed COVID-19 patient \\
\hline & & b. Being in a healthcare facility in a country where hospital-associated COVID-19 has been reported \\
\hline & & c. Having been to China, Singapore, Iran, Thailand, Japan, Hong Kong, South Korea \\
\hline & & d. Working where COVID-19 patients are treated \\
\hline \multirow{3}{*}{ 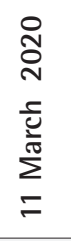 } & A & $\begin{array}{l}\text { Having symptoms of fever and acute respiratory illness, and inability to explain the clinical picture with another condition and being } \\
\text { abroad up to } 14 \text { days before the onset of symptoms }\end{array}$ \\
\hline & B & $\begin{array}{l}\text { Having symptoms of fever and acute respiratory illness, and history of contact with confirmed COVID-19 up to } 14 \text { days before } \\
\text { symptom onset }\end{array}$ \\
\hline & C & $\begin{array}{l}\text { Having fever and signs of severe acute respiratory illness, and having SARI and inability to explain the clinical picture with another } \\
\text { condition }\end{array}$ \\
\hline \multirow{4}{*}{ 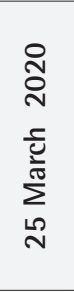 } & A & $\begin{array}{l}\text { Having symptoms of fever and acute respiratory illness, and inability to explain the clinical picture with another condition and being } \\
\text { abroad up to } 14 \text { days before symptom onset }\end{array}$ \\
\hline & B & $\begin{array}{l}\text { Having symptoms of fever and acute respiratory illness, and history of contact with confirmed COVID-19 up to } 14 \text { days before } \\
\text { symptom onset }\end{array}$ \\
\hline & C & $\begin{array}{l}\text { Having symptoms of fever and acute respiratory illness, and having SARI and inability to explain the clinical picture with another } \\
\text { condition }\end{array}$ \\
\hline & D & Sudden onset of fever with cough or shortness of breath and no runny nose \\
\hline \multirow{4}{*}{ 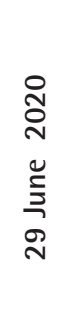 } & A & $\begin{array}{l}\text { Fever, cough, shortness of breath, sore throat, muscle pain, loss of taste and smell or diarrhea, and inability to explain the clinical } \\
\text { picture with another condition and being abroad up to } 14 \text { days before symptom onset }\end{array}$ \\
\hline & B & $\begin{array}{l}\text { Fever, cough, shortness of breath, sore throat, muscle pain, loss of taste and smell or diarrhea, and history of contact with confirmed } \\
\text { COVID-19 up to } 14 \text { days before symptom onset }\end{array}$ \\
\hline & C & $\begin{array}{l}\text { Having symptoms of fever and severe acute respiratory illness, and having SARI and inability to explain the clinical picture with } \\
\text { another condition }\end{array}$ \\
\hline & D & $\begin{array}{l}\text { Having two of symptoms including fever, cough, shortness of breath, sore throat, muscle pain, loss of taste and smell or diarrhea, and } \\
\text { inability to explain them with another condition }\end{array}$ \\
\hline \multicolumn{3}{|r|}{$\begin{array}{l}\text { *SARI: Requirement of hospitalization due to fever, cough and dyspnea, tachypnea, hypoxemia, hypotension, radiological findings and change in consciousness in a patient with acute } \\
\text { respiratory tract infection developed in the last } 14 \text { days. }\end{array}$} \\
\hline \multicolumn{3}{|c|}{ COVID-19: Coronavirus disease-2019 } \\
\hline
\end{tabular}


Taking nasopharyngeal swab: A nostril is entered with a flexible, thin-handled sterile ecuvion. Tears that appear in the eyes of the person indicate that the appropriate anatomical region is reached. After waiting for a few seconds, it is removed by turning. The process is repeated from the other nostril with the same ecuvion and placed in the appropriate transport medium ${ }^{19}$.

The healthcare personnel taking the samples collected the samples from the patients by wearing their personal protective equipment (PPE) and following the infection prevention and control procedures. All samples taken were delivered to the laboratory by triple transport system. It was ensured that the samples were labeled correctly, the request forms were filled in correctly, and clinical information was provided. The laboratory was informed before the sample was sent.

Before the samples came to the laboratory, the barcode information (patient name-surname, date of birth, etc.), the name of the risky area visited and other necessary information (hospital name, doctor's name, etc.) together with other information including the anatomical region and location from which the sample was taken, date and time and clinical symptoms were recorded in the HIMS system by the Provincial Health Directorate.

After this registration process, the barcode of the SARS-CoV-2 PCR test request was removed and sent to our laboratory together with the relevant samples. Since the triple transport container was not opened during the delivery of the samples to the laboratory, the barcodes could not be checked at this stage. Samples were opened in the Biosafety cabinet in the third room and rejected when necessary.

\section{b. Analytical Process}

After the Ministry of Health declared it as "COVID-19 Authorized Diagnostic Laboratory (Group 1)" on March 19, 2020, all samples from Edirne, Kırklareli and Tekirdağ provinces were directed to our laboratory for SARS-CoV-2 PCR testing ${ }^{20}$. Since the SARS-CoV-2 PCR test was started to be studied at Tekirdağ Namık Kemal University at the beginning of April, it was continued with samples from Edirne and Kırklareli. SARSCoV-2 PCR tests, which were carried out using the tuberculosis laboratory on March 21, 2020, were continued to be studied at the new place with the allocation of a separate laboratory on April 27, 2020. This coronavirus laboratory, like the previous one, has three rooms. With the opening of the coronavirus laboratory, tuberculosis tests began to be studied in the tuberculosis laboratory on May 13, 2020.

\section{Polymerase Chain Reaction}

When the SARS-CoV-2 PCR test was first studied, the only PCR device available in the laboratory was Montania 4896 (Anatolia Geneworks, Turkey). It was continued with a single device until August 7, 2020. On this date, two Rotor Gene 0 (Qiagen, Hilden, Germany) devices were purchased for our laboratory. The Montania 4896 (Anatolia Geneworks, Turkey) device was sent to the Molecular Diagnostic Laboratory to study molecular tests such as HBV-DNA, HCV-RNA as before. With the replacement of the only PCR device in the Molecular Diagnostic Laboratory, the closed molecular test requests were reopened and samples were started to be accepted.

While Biospeedy (Bioeksen, İstanbul, Turkey) kit was used for the first six months, after the sixth month, biospeedy (Bioeksen, İstanbul, Turkey), diagnovital (RTA Laboratories, İstanbul, Turkey) and coronex (DS Bio and Nano Technology, Ankara, Turkey) kits were used alternately. While working with each kit, the manufacturer's recommendations were followed. While the kits Diagnovital (RTA Laboratories, İstanbul, Turkey) and coronex (DS Bio and Nano Technology, Ankara, Turkey) examine the ORF1ab and $\mathrm{N}$ gene regions, the biospeedy kits target the RdRp (RNA dependent RNA polymerase) gene region.

\section{Serological Tests}

Some time is required for the antibody response $(\lg M, \lg A$, and $\lg G$ ) to occur in those infected with COVID-19. Although the first antibody response ( $\mathrm{lgM}$ ) begins after five days, detectable antibody positivity occurs 10-13 days after the onset of symptoms in most patients ${ }^{21}$. Whether the detected antibodies provide immunity and when it can be detected ( $\mathrm{IgG})$ are now unclear. The ELISA test is currently used to determine the serological response. In our laboratory, ELISA tests are performed on the roche cobas e 601 device with the roche elecsys kit.

\section{Biosafety}

It is recommended that inactivation of microorganisms be performed in a biosafety cabinet in molecular tests using the standard PCR method. National guidelines on laboratory biosafety should also be followed at all times. Testing of clinical specimens that may contain SARS-CoV-2 should be performed in appropriately equipped laboratories by personnel trained on the relevant technical and safety procedures.

However, if cell culture production of virus or neutralization tests are to be carried out, BSL-3 facilities are required at minimum ${ }^{22}$.

The results from the first opening of the laboratory until June 26, 2020 were entered into the laboratory information management system (LIMS) one by one on the computer in the first room. In order to enter the results, the samples were first sent to the laboratory from external institution requests. The referred samples were transferred to the "waiting samples" section in the laboratory. Samples to be rejected were rejected on this page. The samples included in the study were accepted and transferred to the "not approved" page. According to the evaluations made on the device, the result of the sample was 
entered into the system on this page. The results of all patients were recorded in the laboratory notebook.

\section{c. Postanalytical Process}

With the revisions made in the LIMS system in June, the "worklist" was started to be created on the computer. When the incoming samples were opened in the third room, the barcodes of the samples were read by the barcode reader on the computer there and a "worklist" was created. In this way, it was ensured that the samples fell directly into the "not approved" in the system. Thus, the "worklist" was recorded in LIMS, and the printouts of these lists were taken and the archive of these computer printouts began to be kept instead of the notebook record. Again, with the revisions made on this date, it became possible to perform collective operations while entering the results. After the positives were entered one by one to avoid confusion, negatives were entered under control. At the end of the day, work lists were prepared and added to the laboratory file. Positive samples were reported to the filiation teams by phone.

The samples studied in the postanalytical process were accepted as hazardous waste and were disposed of in accordance with BSL-2 safety precautions. After the laboratory personnel working in the third room finished their work, they went to the second room and took off their disposable PPE and threw them in the waste bin.
After all the samples were finalized, the results of the tests from our university were marked as panic values in the system. The doctors of these patients were called by phone and verbal information was given.

In order to reveal the change in the workforce in the laboratory, the number of samples coming to the bacteriology laboratory was scanned retrospectively and compared with the number of samples belonging to the same month of the previous year.

\section{RESULTS}

The total number of samples arriving at the coronavirus laboratory in the first seven months of the pandemic is 74,943 . 73,773 of them are SARS-CoV-2 PCR test, 1,170 of them are anti-SARS-CoV-2 antibody test. The distribution of SARSCoV-2 PCR test results received in our laboratory by months is given in Table 3. It is seen that the positivity rate decreases rapidly at the end of the first month and starts to rise again in the sixth and seventh months. Anti-SARS-CoV-2 antibody tests were positive at a rate of $1.9 \%$.

Rejected SARS-CoV-2 PCR test requests are shown in Table 4. It is seen that the highest rates are in the first months, and this rate decreases in the following months.

Compared to the previous year, the change in the rates of samples coming to the bacteriology laboratory within months

Table 3. SARS-CoV-2 polymerase chain reaction test results

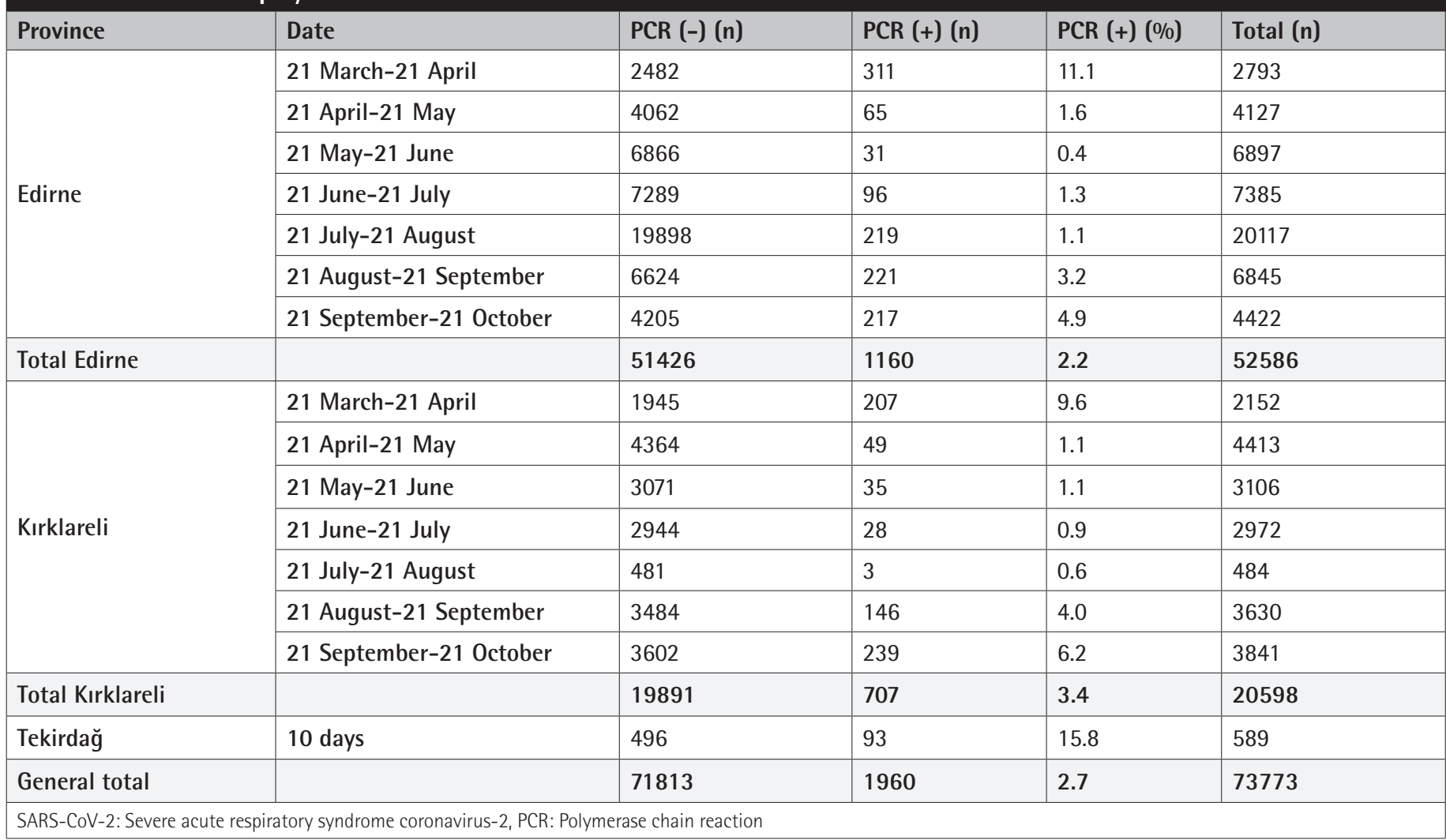


is quite low, especially in the first four months of the pandemic (Table 5).

\section{DISCUSSION}

In 2020, the COVID-19 pandemic has been the most important agenda item both in Turkey and in the world. In extraordinary situations such as pandemics, the society should be guided by strictly defined rules to be taken both locally and globally. Pandemic management should be carried out transparently under the control of the Ministry of Health. When we look at the timeline of the pandemic in the light of our regional data, it is seen that the positivity rates have decreased rapidly after the measures taken to prevent people from contacting each other. The rise of the positivity rate again in the sixth and seventh months of the pandemic also coincides with the period when the measures were relaxed. Considering the size of the COVID-19 pandemic and the fact that it is not known how long it will continue, we believe that the measures should not be relaxed.

PCR testing from lower respiratory tract samples is a more sensitive method than PCR testing from throat or nose swab samples ${ }^{6}$. However, it is not practical to take lower respiratory tract samples from everyone in every environment. For this reason, combined nose-throat swab sample has been the mostly used method in Turkey. With this method, the sample is taken with a swab and placed in viral transport medium and delivered to the laboratory. However, when placing the swab into the viral transport medium, it must be cut at the marked place. Considering that doctors from many different branches take samples in the field, we accept it normal to make mistakes at this point. Since the swab sticks sent without cutting from the appropriate place may cause scattering of the sample in the laboratory, these samples were rejected by giving feedback to the relevant doctor. Leakage of the sample, breakage of the viral transport medium and samples not delivered to the laboratory under appropriate conditions are among the other reasons for rejection. Considering the change in rejected samples within months, it is seen that these rates have decreased considerably thanks to the feedback provided and the strong communication between the laboratory and the clinician.

Medical microbiology laboratory employees have great efforts in the execution of the coronavirus laboratory. Technicians, assistants and academic members working in the medical microbiology laboratory ensured both the running of the coronavirus laboratory and the study of other microbiology tests such as bacteriology, virology, mycology, and serology. In order to work in the most efficient way with a limited workforce, rotations were made within the laboratory.

Although support was received from outside the medical microbiology laboratory in the first months of the pandemic, these assignments were terminated when new technicians appointed to our hospital started in the medical microbiology laboratory in the following months. During this seven-month period, there were significant changes in our hospital. Other departments also had some practices within themselves, such as the closure of some services, the downsizing of some, and the absence of surgery except for emergency surgeries.

\section{Table 4. Rejected SARS-CoV-2 polymerase chain reaction test results}

\begin{tabular}{|l|l|l|l|}
\hline Date & Rejected (n) & Rejected (\%) & Total specimen (n) \\
\hline 21 March-21 April & 172 & 3,1 & 5534 \\
\hline 21 April-21 May & 396 & 4,6 & 8540 \\
\hline 21 May-21 June & 228 & 2,3 & 10003 \\
\hline 21 June-21 July & 56 & 0,5 & 10357 \\
\hline 21 July-21 August & 61 & 0,3 & 20601 \\
\hline 21 August-21 September & 2 & 0,0 & 10475 \\
\hline 21 September-21 October & 0 & 0,0 & 8263 \\
\hline Total & 915 & 1,2 & 73773 \\
\hline SARS-CoV-2: Severe acute respiratory syndrome coronavirus-2 & \\
\hline
\end{tabular}

Table 5. Change in the number of bacteriology samples compared to the previous year

\begin{tabular}{|l|l|l|l|}
\hline & $\mathbf{2 0 1 9}$ & $\mathbf{2 0 2 0}$ & Difference (\%) \\
\hline March & 3677 & 1276 & 65.3 \\
\hline April & 3770 & 375 & 90.1 \\
\hline May & 3141 & 1059 & 66.3 \\
\hline June & 2438 & 1646 & 32.5 \\
\hline July & 2152 & 1950 & 9.4 \\
\hline August & 1878 & 2202 & -17.3 \\
\hline September & 2034 & 2033 & 0.0 \\
\hline October & 2057 & 2092 & -1.7 \\
\hline Total & 21147 & 12633 & 40.3 \\
\hline
\end{tabular}


Pandemic services and intensive care units were opened and started to serve only COVID-19 patients. These changes made in the hospital created significant differences in the number of samples coming to the medical microbiology laboratory when compared to the same months of the previous year. In addition, with all these changes, the needs of the hospital changed and the medical microbiology laboratory responded to this need with rotations and changes made within the laboratory.

\section{CONCLUSION}

As a result, medical microbiology laboratory is a risky unit considering the tests it performs and biosafety measures are always kept in the foreground. In addition, it is thought that the experiences about how the measures taken throughout the country and at the hospital change the work flow in a Microbiology Laboratory will contribute to other laboratory staff.

\section{Ethics}

Ethics Committee Approval: The study was approved by the Scientific Research Ethics Committee of Trakya University (TUTF-BAEK 2021/70, date: 21.12.2020).

Informed Consent: Retrospective study.

Peer-review: Externally peer-reviewed.

\section{Authorship Contributions}

Concept: I.D., Ş.G., B.K., Design: I.D., Ş.G., B.K., Data Collection or Processing: I.D., Ş.G., B.K., Analysis or Interpretation: I.D., Ş.G., B.K., Literature Search: I.D., S..G., B.K., Writing: I.D., Ş.G., B.K.

Conflict of Interest: No conflict of interest was declared by the authors.

Financial Disclosure: The authors declared that this study received no financial support.

\section{References}

1. Dünya Sağlık Örgütü. WHO, Novel coronavirus - China. Erişim tarihi: 19 Ocak 2020. Erişim adresi: http://www.who.int/csr/don/12-january-2020novel-coronavirus-china/en/

2. Coronaviridae Study Group of the International Committee on Taxonomy of Viruses. The species Severe acute respiratory syndrome-related coronavirus: classifying 2019-nCoV and naming it SARS-CoV-2. Nat Microbiol. 2020:5:536-44

3. Dünya Sağlık Örgütü. Timeline: WHO's COVID-19 response. Erişim tarihi: 8 Mayıs 2021. Erişim adresi: https://www.who.int/emergencies/diseases/ novel-coronavirus-2019/interactive-timeline\#!

4. Anadolu Ajansı Arşivi. Türkiye'nin koronavirüsle mücadele politikasına 'Bilim Kurulu' yön veriyor. Erişim tarihi: 1 Haziran 2021. Erişim adresi: https://www.aa.com.tr/tr/koronavirus/turkiyenin-koronavirusle-mucadelepolitikasina-bilim-kurulu-yon-veriyor/1777215

5. International Committee on Taxonomy of Viruses (ICTV). Erişim tarihi: 27 Temmuz 2020. Erişim adresi: https://talk.ictvonline.org/

6. Dünya Sağlık Örgütü. Diagnostic testing for SARS-CoV-2, Interim guidance. Erişim tarihi: 11 September 2020. Erişim adresi: https://www.who.int/ publications/i/item/diagnostic-testing-for-sars-cov-2
7. Guo L, Ren L, Yang S, Xiao M, Chang D, Yang F, et al. Profiling Early Humoral Response to Diagnose Novel Coronavirus Disease (COVID-19). Clin Infect Dis. 2020;71:778-85

8. Türkiye Bilimler Akademisi. COVID-19 Küresel Salgın Değerlendirme Raporu, Haziran 2020. Erişim tarihi: 15 Mayıs 2021. Erişim adresi: http://www.tuba. gov.tr/files/images/2020/kovidraporu/T\%C3\%9CBA\%20Covid-19\%20 Raporu\%206.\%20G\%C3\%BCncelleme.pdf

9. Daily Sabah. China virus sends shockwaves across travel sector, including in Turkey. Erişim tarihi: 17 Mayıs 2021. Erişim adresi: https://www.dailysabah. com/tourism/2020/01/28/china-virus-sends-shockwaves-across-travelsector-including-in-turkey

10. T.C. Sağlık Bakanlığı. Yurt Dışından Dönen Vatandaşlarımızın 14 Gün Kuralına Uymasını Rica Ediyoruz. Erişim tarihi: 23 Mayıs 2021. Erişim adresi: https:// www.saglik.gov.tr/TR,64307/yurt-disindan-donen-vatandaslarimizin-14gun-kuralina-uymasini-rica-ediyoruz.html

11. Türkiye Cumhuriyeti Cumhurbaşkanlığı. Cumhurbaşkanlığı Sözcüsü Kalın: "Korona Virüs'le mücadele sürecini, el birliğiyle rehavete ve paniğe kapılmadan atlatma kabiliyetine sahibiz". Erişim tarihi: 11 Mayıs 2021. Erişim adresi: https://www.tccb.gov.tr/haberler/410/117021/cumhurbaskanligisozcusu-kalin-korona-virus-le-mucadele-surecini-el-birligiyle-rehaveteve-panige-kapilmadan-atlatma-kabiliyetine-sahibiz

12. CNN TÜRK Haber. Son dakika. Bulgaristan karantinayı kaldırdı, Kapıkule Sınır Kapısı'ndan girişler başladı. Erişim tarihi: 17 Mayıs 2021. Erişim adresi: https://www.cnnturk.com/turkiye/son-dakika-bulgaristan-karantinayikaldirdi-kapikule-sinir-kapisindan-girisler-basladi

13. NTV Haber. Sağlık Bakanlığı'ndan Corona virüs genelgesi (Salgın-Pandemi hastaneler belirlendi). Erişim tarihi: 15 Mayıs 2021. Erişim adresi: https:// www.ntv.com.tr/saglik/saglik-bakanligindan-corona-virus-genelgesisalgin-pandemi-hastaneler-belirlendi,EpiQFVq3c06DvBIAnx9kag

14. Anadolu Ajansı. THY tüm dış hat uçuşlarını 20 Mayıs'a kadar durdurdu. Erişim tarihi: 1 Haziran, 2021. Erişim adresi: https://www.aa.com.tr/tr/ turkiye/thy-tum-dis-hat-ucuslarini-20-mayisa-kadar-durdurdu/1804138

15. T.C. Resmi Gazete. COVID-19 Kapsamında Kamu Kurum ve Kuruluşlarında Normalleşme ve Alınacak Tedbirler ile İlgili 2020/8 Sayılı Cumhurbaşkanlığı Genelgesi. Erişim tarihi: 1 Haziran 2021. Erişim adresi: https://www. resmigazete.gov.tr/fihrist?tarih $=2020-05-29$ \&tmukerrer $=1$

16. T.C. Resmi Gazete. COVID-19 Kapsamında Kamu Çalışanlarına Yönelik Tedbirler ile İlgili 2020/11 Sayılı Cumhurbaşkanlığı Genelgesi. Erişim tarihi: 1 Haziran 2021. Erişim adresi: https://www.resmigazete.gov.tr/ eskiler/2020/08/20200826-5.pdf

17. T.C. İçşleri Bakanlığı. 81 î Valiliği'ne Koronavirüs Tedbirleri Konulu Ek Genelge Gönderildi. Erişim tarihi: 28 Mayıs 2021. Erişim adresi: https:// www.icisleri.gov.tr/81-il-valiligine-koronavirus-tedbirleri-konulu-ekgenelge-gonderildi-08-09-20

18. NTV Haber. İçişleri Bakanlığı'ndan yeni genelge: Etkinliklere 1 Aralık'a kadar erteleme. Erişim tarihi: 25 Mayıs 2021. Erişim adresi: https://www.ntv. com.tr/turkiye/icisleri-bakanligindan-yeni-genelge-etkinliklere-1-aralikakadar-erteleme,040cYvGiREeRHHeZntபq0

19. T.C. Sağlık Bakanlığı. COVID-19 (SARS-CoV-2 Enfeksiyonu) Genel Bilgiler Epidemiyoloji ve Tanı. Erişim tarihi: 4 Haziran 2021. Erişim adresi: https:// covid19.saglik.gov.tr/Eklenti/39551/0/covid-19rehberigenelbilgilerepidemiy olojivetanipdf.pdf

20. T.C. Sağlık Bakanlığı. COVID-19 Yetkilendirilmiş Tanı Laboratuvarları Listesi. Erişim tarihi: 22 Ekim 2020. Erişim adresi: https://covid19.saglik.gov.tr/TR68720/covid-19-yetkilendirilmis-tani-laboratuvarlari-listesi.html

21. Muench $P$, Jochum $S$, Wenderoth $V$, Ofenloch-Haehnle $B$, Hombach $M$, Strobl $M$, et al. Development and validation of the Elecsys Anti-SARSCoV-2 immunoassay as a highly specific tool for determining past exposure to SARS-CoV-2. J Clin Microbiol. 2020;58:e01694-20.

22. Dünya Sağlık Örgütü. Laboratory biosafety guidance related to coronavirus, Interim guidance, 13 May 2020. Erişim tarihi: 25 Ekim 2020. Erişikm adresi: https://apps.who.int/iris/bitstream/handle/10665/332076/WHO-WPE-GIH2020.3-eng.pdf?sequence $=1$ ctisAllowed $=y$ 